\title{
Factors Influencing Adoption of Agro-Forestry among Smallholder Farmers in Toungo, Southeastern, Adamawa State, Nigeria
}

\author{
Jamala, G. $\mathrm{Y}^{1^{*}}$, H. E. Shehu ${ }^{2}$, J. J. Yidau ${ }^{1}$ and L. Joel ${ }^{1}$ \\ ${ }^{1 *}$ Adamawa State College of Agriculture, Ganye, Nigeria \\ ${ }^{2}$ Adamawa State University, Mubi, Adamawa State, Nigeria
}

\begin{abstract}
Agroforestry technologies have been extensively researched and introduced to smallholder farmers in Nigeria for over two decades. Despite the research and extension effort over this period, not many farmers have adopted these technologies. In view of this, the study was conducted to assess factors influencing the adoption of agroforestry practices. The study was carried out in Toungo Southeastern fringe of Adamawa State, Nigeria, situated in the Southern guinea Savanna zone. Data were collected with pre-tested questionnaires administered to 100 farmers-household heads, randomly selected from the two Districts of the Local Government Area. Information was gathered on the age, gender, marital status, educational level and years of farming experience, major occupation household size and farm size of the respondents. Others include farmers' awareness of and involvement in Agroforestry systems, willingness to plant, retain or take care of trees planted, tree species commonly retained/planted on farmland and other information relevant to the study. Data were analyzed using a descriptive statistics, $T$-test and $\chi^{2}$ models. The $\chi^{2}$ test result revealed that the educational level of the respondents correlated highly with the respondents major occupation $(p<0.01) \cdot \chi^{2}$ test shows that there was significant relationship $(p<0.01)$ between the respondents' level of education and awareness of agroforestry systems. This means that farmers who acquire some level of education are more likely to perceive new technologies than the ones who have no any form of education. The t-test result shows a significant difference with respect to the type of agroforestry practices among the respondents. The deliberate retaining of trees on farmland was the most common agroforestry practice in the study area as indicated. The farmers maintained that tree species are retained to provide various uses such as Wind break (8\%), Fodder (16\%), Fuel wood (6\%), Staking material (4\%), Source of Income (14\%), Soil improvement (28\%), Medicinal herbs $(10 \%)$, Shade (6\%) and constructional materials $(8 \%)$. The result of the t-test shows a significant difference $(p<0.01)$ in the proportion of those aware of agroforestry practices and those not aware. $82 \%$ maintained that they are aware of the potentials of agroforestry while $18 \%$ claimed not to be aware. $76 \%$ of the respondents indicated that they were willing to retained/plant trees on their farm land. Farmers' responses to questions on some reasons for unwillingness to practice agro-forestry technologies were different. Generally none of the reasons provided in the survey could be considered to greatly influence agro-forestry practice. The result indicated that lack of knowledge and lack of seed/planting materials influence the adoption of agro-forestry more than other factors do. Generally, level of awareness is high. Therefore lack of awareness was not one of the main reasons preventing farmers from adopting agroforestry. Since lack of knowledge and lack of seed were said to influence agroforestry practice more than would lack of awareness, limited land, and lack of interest, they perhaps deserve particular attention when planning and implementing agroforestry development.
\end{abstract}

Key words: Agroforestry, Taungya, Smallholder, Farmers, Adoption, Willingness

\section{Introduction}

About 70 percent of Nigeria's population live in the rural areas and the majority of these people depend on agriculture for improving livelihoods (Odurukwe 2004). However smallholder agriculture faces many challenges including low productivity, high dependence on rain-fed agriculture, insecurity of the traditional land tenure system and environmental degradation due to unsustainable agricultural practices. As a result of these challenges, smallholder agriculture remains at low productivity and this has led to high incidence of poverty among rural smallholder farmers (Opio, 2001).

Part of the solution to address low land productivity is the development of new agroforestry technologies. In Nigeria, agroforestry technologies have been trialled at research stations since 1980 and also on farms since 1984 in collaboration with farmers (Franzel et al., 2002). In particular improved fallows and biomass transfer technologies have been developed (Kwesiga and Coe, 1994; Kwesiga et al., 1999; Kwesiga et al., 2003). A quick and easy method for replenishing nitrogen and other trace elements would be use of inorganic fertilisers; however, these are beyond most of the rural farmers' budgets. Therefore agroforestry technologies offer an alternative solution to resource-constrained smallholder farmers, who in the absence of 
inorganic fertilisers would otherwise grow crops without addressing nutrient requirements and harvest little or nothing for storage. According to Lundgren and Raintree (1982) Agroforestry is a "collective name for land-use systems and technologies where woody perennials (trees, shrubs, palms, bamboos, etc.) are deliberately used on the same land-management units as agricultural crops and/or animals, in some form of spatial arrangement or temporal sequence".

Nair (1993) pointed out that the presence of woody perennials in agroforestry systems may affect several bio physical and bio-chemical processes that determine the health of the soil substrate. The impacts of trees on soil include: amelioration of erosion, primarily through surface litter cover and under story vegetation; maintenance or increase of organic matter and diversity, through continuous degeneration of roots and decomposition of litter; nitrogen fixation; enhancement of physical properties such as soil structure, porosity, and moisture retention due to the extensive root system and the canopy cover; and enhanced efficiency of nutrient use because the-tree-root system can intercept, absorb and recycle nutrients in the soil that would otherwise be lost through leaching (Sanchez, 1987).

Puri and Bangarawa, (1992) pointed out that the choice of tree species is the most important factor to be considered in agroforestry practices. On the other hand Foroughbackhch (1992) stated that the choice of tree species be made after careful consideration of their adaptability for growth and benefit for rural populace. In a previous study conducted by Obi and Tuley (1973) they found out that leguminous species such as Faidherbia albida and Leucaena leucocephala cause a considerable improvement on crop yields. Okali and Nwoboshi (1977) recorded poor performance of crops on apparently rich Tectona grandis and Eucalyptus camadulensis soil. The farmer's preference of forest trees would definitely be due to their potentials and adaptability to the land area.

In a previous research conducted by Kwesiga et al. (2003) and Mafongoya et al. (2003) they found out that the species such as Sesbania sesban (L.) Merr., Tephrosia vogelii Hook .f., Cajanus cajan, Gliricidia sepium (Jacq.) Walp., Leucaena leucocephala (Lam.) De Wit., Acacia angustissima and Tephrosia candida (Madagascar) are suitable for agroforestry.

Franzel et al. (2001) observed high adoption of agroforestry technologies by farmers. While in a separate study conducted by Ajayi, (2007) shows that adoption of these technologies is low. According to Phiri et al. (2004) and Keil et al. (2005) farmers that are involved in on-farm experimentation of agroforestry technologies with the researchers are more likely to adopt than those who are not. Keil also considered information and knowledge about a given technology as key to adoption of agricultural practices, especially ones associated with ecological benefits.

Ajayi et al. (2003) conducted studies and found out that farm size have a positive association with farmers' decisions to plant and even continue with agroforestry practices. Age is another factor that has been extensively considered as a socio-economic factor influencing adoption of agroforestry (Ajayi et al., 2003). Other factors include availability of labour supply, the degree of innovativeness of individual farmers (Ajayi et al., 2006) and expensive fertilizer prices (Gladwin et al., 2002).

In a separate studies conducted by Peterson (1999) and Kwesiga et al. (2003) they found out that Lack of planting materials (seed and seedlings) is another factor considered to constrain establishment of agroforestry. Gladwin et al. (2002) and Keil et al. (2005) established that the probability of adoption increases when farmers perceive low soil fertility as their current problem. In most cases however, even when low crop productivity is observed, farmers have been known to continue cultivating same plots; or where natural forests still exist, to extend their agricultural fields by opening up new forests, a practice attributed to enhance environmental degradation. With the latter case being less practiced due to dwindled forest areas, alternatives such as agroforestry that allow intensive management of already cultivated areas for resource poor-farmers offer best solution.

According to Rogers (2003), adoption occurs when one has decided to make full use of the new technology as a best course of action for addressing a need. Adoption is determined by several factors including socioeconomic, environmental, and mental processes that are governed by a set of intervening variables such as individual needs, knowledge about the technology and individual perceptions about methods used to achieve those needs (Thangata \& Alavalapati, 2003).

In Nigeria, natural fallows have been a common practice among smallholder farmers for restoring soil fertility. However with rapid population increase and land use pressure, these fallows have been reduced to below the minimum threshold required for the system to sustain itself. As a response to declining land productivity, farmers open up forests to expand to new areas and this has led to loss of extensive forests and subsequent land degradation. As findings on factors that influence adoption of agroforestry vary between studies, it is necessary to further probe the adoption process so as to understand what actually influences adoption of agroforestry as these would be instrumental in furthering their effective promotion and accelerating their equitable uptake. Literature suggests that successful adoption depends on favourable convergence of technical, economic, institutional and policy factors (Feder et al., 1985; Rogers, 2003). 


\section{Materials and Methods}

Study Area

The study was carried out in Toungo local government area of Adamawa State. The local government lies between Latitude $8^{\circ} 7^{\prime}$ and Longitude $12^{\circ} 3^{\prime}$ East. It is bounded by Ganye to the north, Taraba state to the west and south and to the east the republic of Cameroon. It has a land mass of $5479.5 \mathrm{~km}^{2}$ and a population of 52,040 (Adebayo, 1999; NPC, 2007). The mean annual temperature of the study area is $26.7^{\circ} \mathrm{C}$ while the mean annual rainfall ranges between $1100 \mathrm{~mm}$ and $1600 \mathrm{~mm}$ with a distinct dry season which begins in November and ends April and the wet season begins in April and ends in October or sometimes in November. The areas are located within the Guinea Savannah zone of the Nigeria's vegetation zones (Adebayo, 1999).

The major economic activity in the area is agriculture. Food crops grown in the area are maize, sorghum, cowpea, cassava and potatoes. While cash crops such as groundnuts, rice, yam and sugarcane are produced in large quantities. Major livestock reared in the zone are cattle, sheep and goats (ADSEEDS, 2004)

\section{Design of the Study}

The method used for this study is survey research method. The survey method was adopted due to the nature of the research, which involves practical issues. The questionnaire was designed to find out views concerning factors influencing the adoption of agro-forestry among smallholder farmers in Toungo Local Government area, Adamawa State. The target population comprises of all the Districts in Toungo local government area.

The questionnaire was administered to a total of 50 farmers in each of the two Districts of the local government area. All selected farmers are household heads. The total number of questionnaires administered and retrieved thus was 100 . The questionnaire was designed to gather information on farmers' awareness and adoption of Agroforestry systems, their willingness to plant trees, retain trees on farmland during cultivation or take care of those planted. Information was also collected on farm size(s), tree species commonly retained/planted on farmland other vital information relevant to the study. All questionnaires were completed and retrieved on site because most respondents had no formal education.

Data obtained were analyzed using descriptive statistics that include the use of frequency distributions, means and percentages. Chi-square $\left(\chi^{2}\right)$ was used to test for the presence of associations in the variables obtained. Student t-test was used to verify the presence of significant differences between respondents' gender, proportion of those aware of agroforestry practices and those who are not aware.

\section{Results and Discussion}

Table 1 shows the age, gender, marital status, educational level and years of farming experience, major occupation household size and farm size of the respondents. The results of t-test indicate the presence of significant differences $(p<0.01)$ in age and household size distribution of the respondents. This shows that there is a wide variation in distribution of respondents over different age groups and household sizes. Majority of the respondents $(46 \%)$ were found in the age group $41-50$ years followed by $34 \%$ between $30-40$ years. The least age group was between $20-29$ years $(20 \%)$. Majority (68\%) of the respondents had more than five persons in their households. This means that there is a good source of labour. An explanation to this is that more adult members in a household means that more quality labour would be available for carrying out farming activities and the practice of agroforestry would not pose any problem. This agreed with the findings of Villano and Fleming (2004).

It can be seen in Table 1 that $64 \%$ are male and $36 \%$ women involved in agroforestry. The results of the t-test show a significant difference $(\mathrm{P}<0.01, \mathrm{df}=99)$ in gender distribution among the respondents. The proportion of males is significantly higher than that of females. Majority of the respondents are married $(76 \%)$ while $24 \%$ are singles.

Table 1 indicates that $28 \%$ of the respondents have no formal education, while $72 \%$ have various level of education ranging from adult education (18\%), primary education (24\%), secondary education (14\%) and tertiary education (16\%). This implies that the respondents could adopt most improved farming technologies due to their enhanced ability to acquire technical knowledge. Besides, farmers who have some level of education respond readily to improved technology, such as application of fertilizers, use of pesticides and improved planting materials thus increasing their productivity. According to Amaza and Tashikalma (2003), the literacy level of farmers is important as it determines the rate of adoption of improved technology for increased productivity. Also, Adekunle (2009) pointed out that the level of education of farmers will directly affects their ability to adapt to change and to accept new ideas. The $\chi^{2}$ test results revealed that the educational level of the respondents correlated highly with the respondents major occupation $(p<0.01)$. The result of $\chi^{2}$ test shows that there is significant relationship $(\mathrm{p}<0.01)$ between the respondents' level of education and awareness of agroforestry systems. This means that farmers who acquire some level of education are more likely to perceive new technologies than the ones who have no any form of education. 
The result in Table 1 shows that $42 \%$ has 16 to 20 years of farming experience and $32 \%$ had 11 to 15 years. This shows that with more years of farming experience, farmers tend to be more efficient in production through learning by doing. From Table 1 it can be seen that the di-occupational respondents constitute about $62 \%$. This means that majority of them had acquired capital formation through other avenues of income to support their farming activities. The diversification serves as a security to the di-occupational farmers should one of the ventures fail. While 38 percent are full time farmers, which mean that apart from farming activities they do not have other sources of incomes.

T-test result show that there is significant difference $(\mathrm{p}<0.01)$ in respondents' farm size. The farm size varied from 1 to 5 ha with the majority (59\%) having a farm size of between 1 and 2 hectares. This implies that the respondents' are a typical characteristic of smallholders farmer possession a relatively small landholdings use to produce what they need for their own family with little extra being offered for sale. Forty one percent of respondents have a farm size of between 3 and 5 hectares.

Table 1: Summary of some socio-economic profile of the respondents

\begin{tabular}{|c|c|c|}
\hline Variables & Frequency $(\mathrm{n}=100)$ & Percentage \\
\hline \multicolumn{3}{|l|}{ Age } \\
\hline $20-29$ & 20 & 20 \\
\hline $30-40$ & 34 & 34 \\
\hline $41-50$ & 46 & 46 \\
\hline Total & 100 & 100 \\
\hline T-test result & $\mathrm{P}=0.0001, *$ significant $(\mathrm{P}<0.01)$ & \\
\hline \multicolumn{3}{|l|}{ Gender } \\
\hline Female & 36 & 36 \\
\hline Male & 64 & 64 \\
\hline Total & 100 & 100 \\
\hline T-test result & $(\mathrm{P}<0.01), \mathrm{df}=99, \mathrm{P}=0.0001, *$ significant & \\
\hline \multicolumn{3}{|l|}{ Marital Status } \\
\hline Married & 76 & 76 \\
\hline Single & 24 & 24 \\
\hline Total & 100 & 100 \\
\hline \multicolumn{3}{|c|}{ Education Qualification } \\
\hline No Formal Education & 28 & 28 \\
\hline Adult Education & 18 & 18 \\
\hline Primary Education & 24 & 24 \\
\hline Secondary Education & 14 & 14 \\
\hline Tertiary Education & 16 & 16 \\
\hline Total & 100 & 100 \\
\hline \multicolumn{3}{|l|}{ Years of Experience } \\
\hline $5-10$ & 10 & 10 \\
\hline $11-15$ & 32 & 32 \\
\hline $16-20$ & 42 & 42 \\
\hline $21-25$ & 12 & 12 \\
\hline $26-30$ & 4 & 4 \\
\hline Total & 100 & 100 \\
\hline \multicolumn{3}{|l|}{ Major Occupation } \\
\hline Full time Farmers & 38 & 38 \\
\hline Civil Servant/Farmer & 48 & 48 \\
\hline Trader/Farmer & 14 & 14 \\
\hline Total & 100 & 100 \\
\hline$\chi^{2}$ & $\mathrm{P}=0.0001, *$ significant, $\mathrm{df}=2(\mathrm{P}<0.01)$ & \\
\hline \multicolumn{3}{|l|}{ Household Size } \\
\hline $3-5$ & 32 & 32 \\
\hline $5-9$ & 40 & 40 \\
\hline $10-13$ & 14 & 14 \\
\hline$>14$ & 14 & 14 \\
\hline Total & 100 & 100 \\
\hline \multicolumn{3}{|c|}{ Distribution of Respondents based on Farm size } \\
\hline 1-2 На & 59 & 59 \\
\hline 3-5 Ha & 41 & 41 \\
\hline Sub-total & 100 & 100 \\
\hline T-test result & $\mathrm{df}=99, \mathrm{P}=0.0001, *$ significant,$(\mathrm{P}<0.01)$ & \\
\hline
\end{tabular}

Source: Field Survey, 2012

Adoption of agroforestry systems by respondents is presented in Table 2. The t-test result shows a significant difference with respect to the type of agroforestry practices among the respondents. The deliberate retaining of trees on farmland was the most common agroforestry practice in the study area as indicated. The 
farmers maintained that these species are retained to provide various uses such as Wind break (8\%), Fodder $(16 \%)$, Fuel wood (6\%), Staking material (4\%), Source of Income (14\%), Soil improvement (28\%), Medicinal herbs $(10 \%)$, Shade $(6 \%)$ and constructional materials $(8 \%)$.

Table 2 shows the level of awareness of agroforestry practices. $82 \%$ maintained that they are aware of the potential of agroforestry while $18 \%$ claimed not to be aware. The results of the t-test (Table 2) shows a significant difference $(\mathrm{p}<0.01)$ in the proportion of those aware of agroforestry practices and those not aware. $76 \%$ of the respondents were willing to retained/plant trees (Table 2). The species retained include Tamarindus indica L., Parkia biglobosa (Jacq), Gmelina arborea (Roxb), Mangifera indica, Prosopis Africana, Acacia senegal L., Azadiracta indica Adr. Juss, Moringa oleifera Lam., Adamsonia digitata and Jatrofa Carcus.

Table 2: Awareness and Participation of the Respondents' in Agro-forestry

\begin{tabular}{|c|c|c|}
\hline Response & Frequency & Percent \\
\hline \multicolumn{3}{|c|}{ Awareness of Agro-forestry systems by Respondents } \\
\hline Yes & 82 & 82 \\
\hline No & 18 & 18 \\
\hline Sub-total & 100 & 100 \\
\hline \multirow{2}{*}{\multicolumn{3}{|c|}{$\begin{array}{l}\mathrm{P}=0.001,{ }^{*} \text { significant }(\mathrm{P}<0.01) \\
\text { Type of Agro-forestry practice by Respondents }\end{array}$}} \\
\hline & & \\
\hline Retaining tree on farmland & 38 & 38 \\
\hline Alley cropping & 28 & 28 \\
\hline Mulching with tree species & 18 & 18 \\
\hline Approved Taungya & 16 & 16 \\
\hline Sub-total & 100 & 100 \\
\hline \multicolumn{3}{|c|}{ Willingness to plant/retain trees by Respondents } \\
\hline Yes & 76 & 76 \\
\hline No & 24 & 24 \\
\hline Sub-total & 100 & 100 \\
\hline \multicolumn{3}{|c|}{ Purpose of retaining trees by Respondents } \\
\hline Wind break & 8 & 8 \\
\hline Fodder & 16 & 16 \\
\hline Fuel wood & 6 & 6 \\
\hline Staking material & 4 & 4 \\
\hline Source of Income & 14 & 14 \\
\hline Soil improvement & 28 & 28 \\
\hline Medicinal herbs & 10 & 10 \\
\hline Shade & 6 & 6 \\
\hline constructional materials & 8 & 8 \\
\hline Sub-total & 100 & 100 \\
\hline \multicolumn{3}{|c|}{ Types of tree species retained/Density/ha } \\
\hline Tamarindus indica $L$. & 8 & \\
\hline Parkia biglobosa (Jacq) & 16 & \\
\hline Gmelina arborea (Roxb) & 6 & \\
\hline Mangifera indica & 4 & \\
\hline Prosopis Africana & 14 & \\
\hline Acacia senegal $L$. & 8 & \\
\hline Azadiracta indica Adr. Juss & 6 & \\
\hline Moringa oleifera Lam. & 34 & \\
\hline Adamsonia digitata & 16 & \\
\hline Jatrofa Carcus & 46 & \\
\hline
\end{tabular}

Source: Field Survey, 2012

The result in Table 2 revealed that $82 \%$ of the respondents are aware of the agroforestry as a farming system. This indicates that agroforestry is not a new system of agricultural practice to the farmers in the study area.

The responses of farmers in Table 2 show that majority of the farmers (38\%) retained trees on their farmlands and the remaining farmers practice various forms of agroforestry such as alley cropping, mulching with tree species and approved Tungya system of land use.

Majority of the respondents $(76 \%)$ maintained that they are willing to plant trees in their farm land and at the same time retained some valuable species of trees. The remaining indicate unwillingness, this may be either due to lack of ownership of land or are not aware of the importance of agroforestry. 
The study revealed that the respondents either plant trees for additional income, food, firewood, staking materials, constructional materials, soil improvement, fodder, shade, or medicinal herbs (Table 2). This is in consonance with Adewusi (2006) who stated that farmers plant or retain trees on their farm land, both for food, income, soil improvement, environmental amelioration and for shade during the harsh weather period.

The result in Table 2 shows that various tree species ranging from leguminous and non-leguminous, medicinal plants; tree crops and economic trees were either retained or planted by the farmers in their farm lands.

Table 3: Distribution of Respondents based on Unwillingness to practice Agro-forestry

\begin{tabular}{lcc}
\hline Response & Frequency & Percent \\
\hline Limited land & 14 & 14 \\
Lack of interest & 12 & 12 \\
Lack of knowledge/skill & 30 & 30 \\
Lack of seeds & 24 & 24 \\
planting materials & 20 & 20 \\
Sub-total & 100 & 100 \\
\hline
\end{tabular}

Source: Field Survey, 2012

Farmers' responses to questions on some reasons for unwillingness to practice agro-forestry technologies were different (Table 3). The result indicates that lack of knowledge and lack of seed/planting materials are important factors that could influence the adoption of agro-forestry more than other factors do

Generally, level of awareness is high. Therefore lack of awareness was not one of the main reasons preventing farmers from adopting agroforestry (Table 2). Since lack of knowledge and lack of seed were said to influence agroforestry practice more than would lack of awareness, limited land, and lack of interest, they perhaps deserve particular attention when planning and implementing agroforestry development.

\section{Conclusion and Recommendations}

This study examined the factors influencing the adoption of agroforestry practices in Toungo Southeastern fringe of Adamawa State, Nigeria, situated in the Southern guinea Savanna zone. The practice of agroforestry in the study area is fundamentally due to the presence of people without farmland, availability of fertile land under forest cover, population growth leading to an increase in demand for food and forest products. The ecological, economic and environmental roles of well-planned agroforestry for rural livelihood and sustainable development are numerous. Agroforestry could provide more trees available for local consumption and sale. It also has the ability to resolve conflicts among various land users as a multiple land use system.

Since the majority of the farmers are willing to plant and retain trees, and take care of those planted, they should be encouraged by the government to do so. Seedlings and seeds should be distributed to farmers.

Agroforestry is a means of increasing food production and at the same time, it makes wood available to rural dwellers. However, there is a need to improve both formal and informal Agroforestry education among the rural communities for agroforestry to become more widely accepted by local populations. To effectively improve rural living standards, agroforestry should form part of an integrated rural development programme and thereby meet more of the farmer's basic needs than it presently does. Technical assistance is needed to facilitate the spread of agroforestry practices. More so, adequate information is required to keep farmers abreast of current trends and development in the practices of agroforestry. Provision of economic incentives by the forestry department to farmers participating in agroforestry practices should be considered. Farmers in the rural areas should be encouraged to go into agroforestry by the relevant government agencies so that they can benefit from yield of the crops and additional income from the sales of the tree products such as fruits, oils, staking materials, constructional materials, medicinal herbs, soup condiments, wood and other unquantifiable benefits.

\section{References}

[1] Adebayo, A.A. (1999). Climate I\&II (Sunshine, Temperature, Evaporation and Relative humidity: In Adebayo, A.A. and Tukur, A.L. (eds) Adamawa in Maps, paraclete publishers Yola-Nigeria. Pp $15-30$.

[2] Adekunle , V. A. (2009). Contributions of agroforestry practice in Ondo State, Nigeria, to environmental sustainability and sustainable agricultural production. Afrika Focus -Volume 22, Nr. 2, 2009 -pp. 27-40

[3] Adewusi, H.G. 2006 Agroforestry Practices and Species Preference in Kano State. Potentials for Improvement. Production Agriculture and Technology (PAT). Vol.2. 2-4.

[4] Adewuyi, S. A and Okunmadewa, F.Y (2001). Economic Efficiency of Crop Farmers in Kwara State, Nigeria, Nigerian Agricultural development Studies, 2(i): $45-47$.

[5] Ajayi, O. C., Akinnifesi, F. K., Sileshi, G., \& Chakeredza, S. (2007). Adoption of renewable soil fertility replenishment technologies in the southern African region: Lessons learnt and the way forward. Natural Resources Forum, 31(4), 306-317.

[6] Ajayi, O. C., Franzel, S., Kuntashula, E., \& Kwesiga, F. (2003). Adoption of improved fallow technology for soil fertility management in Zambia: Empirical studies and emerging issues. Agroforestry Systems, 59(3), 317-326.

[7] Ajayi, O. C., Massi, C., Katanga, R., \& Kabwe, G. (2006). Typology and characteristics of farmers planting improved fallows in southern Africa. Zambian Journal of Agricultural Sciences, 8(2), 1-5.

[8] Amaza, P.S and Tashikalma, A.K (2003). Technical Efficiency of Groundnuts in Adamawa State, Nigeria, Journal of Arid Agriculture, 13: $127-1311$. 
[9] Feder, G., Just, R. E., \& Zilberman, D. (1985). Adoption of Agricultural Innovations in Developing Countries: A Survey. Economic Development and Cultural Change, 33(2), 255

[10] Forough backhch, R. 1992 Establishment and Growth Potential of Firewood Species in Northeastern Mexico. Agroforestry Systems 19 (2):95-108

[11] Franzel, S., Coe, R., Cooper, P., Place, F., \& Scherr, S. J. (2001). Assessing the adoption potential of agroforestry practic es in subSaharan Africa. Agricultural Systems, 69(1-2), 37-62.

[12] Franzel, S., Phiri, D., \& Kwesiga, F. (2002). Assessing the adoption potential of improved fallows in eastern Zambia. In S. Franzel \& S. J. Scherr (Eds.), Trees on the Farm: Assessing the adoption potential of Agroforestry Practices in Africa (pp. 37-64). Wallingford, UK,: CAB International.

[13] Gladwin, C. H., Peterson, J. S., \& Mwale, A. C. (2002). The Quality of Science in Participatory Research: A Case Study from Eastern Zambia. World Development, 30(4), 523-543.

[14] Gladwin, C. H., Peterson, J. S., Phiri, D., \& Uttaro, R. (2002). Agroforestry adoption decisions, structural adjustment and gender in Africa. In C. B. Barrett, F. Place \& A. A. Aboud (Eds.), Natural Resources Management in African Agriculture: Understanding and improving current practices (pp. 115-128). Wallingford, UK; New York, USA: CAB International in association with the International Cenctre for Research in Agroforestry.

[15] Hudson, P.C. 1945 Economy of the African peasant. Farm and Forestry, vol. 4, No. 1. pp54.

[16] Keil, A., Zeller, M., \& Franzel, S. (2005). Improved fallows in smallholder maize production in Zambia: do initial testers adopt the technology? Agroforestry Systems, 64, 225-236.

[17] Kwesiga, F., Akinnifesi, F. K., Mafongoya, P. L., McDermott, M. H., \& Agumya, A. (2003). Agroforestry research and development in southern Africa during the 1990s: Review and challenges ahead. Agroforestry Systems, 59(3), 173-186.

[18] Kwesiga, F., \& Coe, R. (1994). The Effect of Short-Rotation Sesbania-Sesban Planted Fallows on Maize Yield. Forest Ecology and Management, 64(2-3), 199-208.

[19] Kwesiga, F., Franzel, S., Place, F., Phiri, D., \& Simwanza, C. P. (1999). Sesbania sesban improved fallows in eastern Zambia: Their inception, development and farmer enthusiasm. Agroforestry Systems, 47(1-3), 49-66.

[20] Lundgren, B. O., and J. B. Raintree, 1982. Sustained Agroforestry. In B. Nestel (ed.) Agricultural Research for Development: Potential and Challenges in Asia. ISNAR, The Hague, Netherlands. pgs 37 - 49.

[21] Mafongoya, P. L., Chintu, R., Chirwa, T. S., Matibini, J., \& Chikale, S. (2003). Tephrosia species and provenances for improved fallows in southern Africa. Agroforestry Systems, 59(3), 279-288.

[22] Nair, P. K. R., 1993. An Introduction to Agroforestry. Kluwer, Boston.

[23] National Population Commission, NPC (2007). Federal Republic of Nigeria Official Gazette No. 24 Volume 94 Lagos, Nigeria.

[24] Obi, J.K. and Tuley, P. 1973 The Bush Fallow and Farming in the Oil Palm Belt of South Eastern Nigeria. Report 161.

[25] Odurukwe, S. 2004. Agroforestry in peri-urban cities of Abia State, Nigeria. UM Magazine 8-9.

[26] Okali, D.U.U and Nwoboshi, L.C. 1977 A Preliminary Study of Maize Planted among Coppiced Teak. Mimeograph. Department of Forest Resources Management University of Ibadan, Nigeria. 8pp.

[27] Opio, C. (2001). Biological and Social Feasibility of Sesbania fallow practice in Small Holder Agricultural Farms in Developing Countries: A Zambian Case study. Environmental Management, 27(1), 59-74.

[28] Phiri, D., Franzel, S., Mafongoya, P. L., Jere, I., Katanga, R., \& Phiri, S. (2004). Who is using the new technology? The ass ociation of wealth status and gender with the planting of improved tree fallows in Eastern Province, Zambia. Agricultural Systems, 79(2), 131-144.

[29] Puri, S and Bangarawa, K.S. 1992 Effects of Trees on the Yield of Irrigated Wheat Crop in Semi-arid Regions. Agroforestry System 20 (3): 229-241.

[30] Rogers, E. M. (1995). Diffusion of Innovations (4th ed.). New York, USA: The Free Press.

[31] Rogers, E. M. (2003). Diffusion of Innovations (Fifth ed.). New York: The Free Press.

[32] Sanchez, P. A., 1987. Soil productivity and sustainability in agroforestry systems. In H. A.

[33] Seppler and P. K. R. Nair (eds), Agroforestry: A Decade of Development. International Council for Research in Agroforestry, Nairobi, Kenya. pp $205-223$.

[34] Thangata, P. H., \& Alavalapati, J. R. R. (2003). Agroforestry adoption in southern Malawi: the case of mixed intercropping of Gliricidia sepium and maize. Agricultural Systems, 78(1), 57-71.

[35] Villano, R. and Fleming, E. (2004). Analysis of Technical Efficiency in a Rain-fed Lowland Rice Environment in Central Luzon Philippines using a stochastic frontier paper series in Agricultural and Resource Economics No. 2004 - 15, University of New England, Armidale. 